SB 741

.D3 H3

Copy 1 



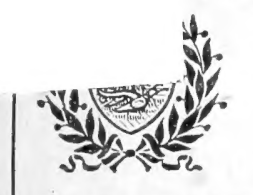

BULLETIN No. 453

Contribution from the Bureau of Plant Industry. WM. A. TAYLOR, Chief

Washington, D. C.

PROFESSIONAL PAPER

January 20, 1917

\section{THE CONTROL, OF DAMPING-OFF OF CONIFEROUS SEEDLINGS.}

By Carl Hartley, Forest Pathologist, and Roy G. Pierce, Forest Assistant, Office of Investigations in Forest Pathology.

\begin{tabular}{|c|c|c|}
\hline \multicolumn{2}{|c|}{ Page. } & \\
\hline The disease.. & 1 & Cost of disinfectant treatments............ \\
\hline Economic importance of damping-ofl ........ & 1 & Secondary advantages from disinfectant treat- \\
\hline Relation between nursery methods and the & & lents \\
\hline control of damping-off ....................... & 3 & Conclusions as to soil disinfectants... \\
\hline $\begin{array}{l}\text { Tests of soil disiniection for the control of } \\
\text { damping-off. }\end{array}$ & 6 & Soil treatments recommended...... \\
\hline Soil-disinfection tests summarized & 14 & \\
\hline
\end{tabular}

\section{THE DISEASE.}

Damping-off is a term commonly used to describe the disease causing the death of very young seedlings due to various parasitic fungi. The damping-off of conifers in the United States has been found to be caused by the fungi Pythium debaryanum Hesse, Fusarium moniliforme Sheldon, and the common American Rhizoctonia, usually referred to as Corticium vagum B. and C. var. solani Burt. Other species of Fusarium and other fungi are probably also concerned to a less extent. Most affected seedlings promptly fall over and decay. Those which are not attacked till they are 4 to 8 weeks old may have such wiry stems that they merely turn brown and remain standing ofter death. This later type of injury is caused by parasites in the wue way as the decay of the more succulent younger seedlings, though nurserymen do not always recognize it as the same thing.

\section{ECONOMIC IMPORTANCE OF DAMPING-OFF.}

Damping-off has been a handicap to nearly all nurserymen who raise conifers from seed. In most nurseries a large number of seedlings are lost every year. The loss is ordinarily considerably heavier than the nurseryman realizes. Very young seedlings decay and disappear so soon after infection that the number of dead seedlings $60142^{\circ}-$ Bull. $453-17-1$ 
visible at any one time is but a small part of the total loss. Furthermore, many of the seedlings are killed immediately after the seed sprouts and before the seedlings appear above the soil surface. Many failures hitherto attributed to poor germination are in reality due to the work of the damping-off parasites in the sprouting seed, underground. The high price of most evergreen seed makes this loss of young seedlings a serious matter.

The cost of seed ${ }^{3}$ ranges from a minimum price of 50 cents per pound for western yellow pine (Pinus ponderosa Laws.) collected by the United States Forest Service to $\$ 2$ to $\$ 4$ per pound quoted by commercial seedsmen for the native spruces and $\$ 5$ to $\$ 10$ per pound for Norway pine (Pinus resinosi Ait.). The regular annual loss is, however, not the most serious result of the disease. The most troublesome thing from the commercial standpoint is the great variation in the prevalence of the disease. In some seasons the loss is relatively slight, while in others the seed beds may be almost a total loss. The results of a damping-off epidemic are shown by the poor stand in the untreated plats in Plate I. Such epidemics make it impossible for a nurseryman to secure any regularity in production. The difficulty of controlling damping-off has caused many nurserymen to give up raising their own seedling conifers.

The loss from damping-off can not be figured merely on a basis of the number of the seedlings destroyed. The most serious aspect of the disease is the extent to which planting is discouraged by it. Reforestation of watersheds is one of the great needs of the present time. When interest on the cost of a forest plantation is compounded for the 80 or 100 years which must elapse between forest planting and timber cutting, a very slight initial increase in the cost of planting stock becomes a heavy charge against the ultimate timber value of the plantation, on which the owner must depend for direct returns. It is necessary in order to encourage forest planting to eliminate all possible cost items in the establishment of plantations. Both the average loss and the irregularity in production due to damping-off are reflected in the prices of coniferous planting stock, so that the disease must be controlled to give the maximum opportunity for profitable reforestation. It has previously been possible to import pine stock from Europe cheaply. This has resulted in the introduction of very dangerous insect and fungous pests. The importation of all pines is now prohibited, and the danger of the further introduction of parasites on imported stock of other conifers makes it necessary that the domestic nursery industry be developed on an economic scale that will eliminate all need or incentive for importation. To do this, all important native diseases, of which damping-off is the most serious, must be controlled.

${ }^{1}$ Information furnished by the Office of Forest Investigations, United States Forest Servict. 


\section{RELATION BETWEEN NURSERY METHODS AND THE CONTROL OF DAMPING-OFF.}

A great deal has been written, largely in horticultural journals, on the methods best calculated to prevent damping-off. It has been generally agreed that beds should be well drained and aerated and should have no more water or shade than absolutely necessary. Surfacing beds with gravel, coarse sand, or heated sand has also been recommended. All of these measures have value, but all have their limitations. All of them combined are not sufficient to prevent heavy losses when the damping-off parasites are present in sufficient quantity.

\section{THE BEST SOIL FOR SEED BEDS.}

In general, where there is a chance to choose between different seedbed sites it is safest from the standpoint of damping-off control to select a site with a sandy soil. Either because such soils are better drained or because they contain less organic food matter for fungi, damping-off is commonly less troublesome on light than on heavy soils. A sandy soil is by no means a guaranty of freedom from disease, the heaviest damping-off losses in the writers' experience having occurred on a soil consisting of nearly pure sand. Alkaline soils are believed to favor damping-off. If this is found to be the case, it may explain the fact that some of the heaviest losses from dampingoff occur in Nebraska and Kansas rather than in the more humid Eastern States.

Where it is necessary to put seed beds on a soil where damping-off is troublesome, the soil may be improved in various ways. Where sand is easily available, it may pay to haul it in and mix it with the surface soil. Excellent results have been obtained in one case in the writers' experience by making the entire uppor 3 inches of the bed of very sandy subsoil just dug up. A less expensive procedure which has also given indication of value is to cover the seed with subsoil taken from a point so far below the surface that it is likely to be free from parasitic fungi and an unfavorable medium for their growth. It is usually better to cover seed with sand than with heavy soil, and surfacing the beds with coarse sand or gravel after the seed is sown and covered is considered helpful. Surfacing the beds after germination with heated sand applied as hot as the hand can stand has also been recommended. Tests by the writers of hot sand on seed beds in a sandy western soil had no perceptible effect on the disease.

\section{AVOIDANCE OF EXCESSIVE MOISTURE.}

To secure drainage, seed beds are commonly raised from 2 to 3 inches above the paths, and at some nurseries the surface of the bed is arched to increase run-off. This is probably good practice at most nurseries, but on very sandy soils in a dry climate it does not appear to 
have any value whatever. To secure aeration the best eastern nurseries leave their beds entirely open to the wind, or, if side walls are needed to exclude seed-eating animals, they use wire netting only. Yet, at a nursery in western Kansas, after trying the rather expensive netting sides, it was found by forest officers that as good or better results were obtained by using beds with tight board sides. It is well known that excessive moisture and shade must be avoided in the sced beds. However, in sandy soils or in a dry country there is nearly as much danger of getting the beds too dry as of keeping them too wet. Drought often kills large numbers of seedlings in beds left without water.

Aside from common drought injury the effort to keep seed beds dry may result in an entirely different type of trouble. If seed beds are insufficiently shaded and the soil surface is not kept moist, there is at some nurseries serious loss from "white-spot" injury. This injury in seedlings up to 3 weeks of age appears as a whitening and shrinking of the stem just above the ground line. The shrunken area in most cases girdles the stem, the seedling falls over, and death follows. When the injury occurs on one side only it is usually the south or southwest side of the stem that is affected. The symptoms are very much like damping-off, the decided white color of the part of the stem first affected being the most noticeable difference. 'This whitespot injury is caused not by parasites but apparently by heat, with which possibly may also be combined the direct effects of intense light. The temperature at the surface of a dry, loose soil exposed to the sun may exceed $140^{\circ} \mathrm{F}$, a very high temperature for most tender plant tissues to endure for any length of time. White-spot injury is almost always mistaken for damping-off, and has been observed to kill more than half of the seedlings in unshaded beds of even so heatresistant a species as western yellow pine (Pinus ponderosa). In withholding water and shade from coniferous seed beds, nurserymen must be very careful or the loss from drought and white-spot will much exceed the advantage from decreased damping-off loss. Keeping the beds dry is impossible in wet weather and dangerous in dry weather, and it therefore will never be more than a partial control method for damping-off.

\section{FERTILIZERS.}

The relation between soil fertilization and damping-off has been but little investigated. In preliminary tests dried blood and nitrate of soda have apparently favored the damping-off parasites, and their use on pine seed beds is considered inadvisable. However, in Vermont $^{1}$ tankage has given excellent results against damping-off. It is evident that further tests of nitrogenous fertilizers are needed.

1 Gifford, C. M. The damping-off of coniferous seedlings. Vt. Agr. Exp. Sta. Bul. 157, p. 170. 1911. 
Lime in small quantities has had no appreciable effect, while applications at the rate of 1 ton per acre to beds of jack pine (Pinus banksiana Lamb.) in Nebraska have had bad effects. At Burlington, Vt., ${ }^{1}$ wood ashes have been added to seed beds with disastrous results. Lime also caused trouble at Burlington. At Providence, R. I., a mixture of coal and wood ashes tested by Prof. H. H. York seemed to give bad results. Heavy applications of imperfectly rotted horse manure have been known to greatly increase damping-off at the Nebraska nursery, but at the same nursery well-composted manure seems harmless. It is probably safest to manure beds at least a year before seed is to be sown on them. No trouble has been observed to result from the use of green manures, but it may be found that some such crops harbor damping-off parasites and should be avoided. The perennial ragweed of the Southwest (Ambrosia psilostachya DC.) serves as a hold-over host for parasitic strains of Corticium, so that this and any other weeds known to carry seedling parasites should be eliminated from nursery areas.

\section{DENSITY OF SOWING.}

As with truck crops, it is found that pines suffer most from dampingoff when sown too closely. A bed containing a stand of seedlings which is too dense will not only lose more seedlings than a less crowded bed, but it will lose a higher percentage of its seedlings. This is due to the ease with which the parasites spread from one seedling to another in dense stands. It has also been found with jack pine that in tests at two nurseries the damping-off loss in seedlings sown broadcast was only four-fifths as great as in adjacent plats sown in drills. In general, beds sown broadcast seem to suffer less from damping-off than beds sown in drills, though with western yellow pine broadcasting has given no better results than the drill method at the nurseries where comparative tests were made.

TIME OF SOWING.

Another item in nursery practice in which variation may affect damping-off is the time at which seed is sown. At some nurseries it makes little difference when seed is sown. In one season beds sown in early spring suffer least from the disease. The next season the latest sown beds may come out the best. However, at some nurseries it is found that there is a best time and a worst time for seed sowing. In a New Mexico nursery it has been demonstrated that July, the local rainy season, is the worst sowing time from the damping-off standpoint. At two western nurseries (in Nebraska and Colorado) the Forest Service has found that yellow-pine seed beds sown in late autumn are comparatively free from damping-off. Repeated tests during two or three successive seasons are necessary 
to determine for any particular nursery whether or not damping-off losses are regularly less in beds sown at a particular time. It is thought that fall sowing is least likely to succeed in localities in which the soil does not remain constantly frozen during the winter.

TESTS OF SOIL DISINFECTION FOR THE CONTROL OF DAMPING-OFF.

The entire matter of the factors controlling the work of the damping-off parasites and the methods of seed-bed management most likely to decrease the disease needs a great deal of further examination. At present adherence to the best known nursery practice will not avoid considerable annual losses at most nurseries or prevent epidemic years in which the beds of certain species are entire failures. The multiplicity of parasites and the different conditions of soil and climate to be met so complicate the problem that it has been found most profitable to make a direct attack on the parasites by the use of disinfectants rather than wait for results by the indirect means of changed nursery management.

Experiments in seed-bed disinfection have been carried on by the writers or in pursuance of their recommendations for the past seven years and at a number of nurseries. At different times assistance has been rendered by Mr. R. D. Rands, Dr. J. V. Hofmann, Dr. T. C. Merrill, Mr. S. C. Bruner, and Mr. G. G. Hahn.

Definite and satisfactory control of the disease has been secured by soil disinfection at every nursery in which extensive experiments have been conducted, and preliminary tests at additional nurseries indicate that while different places require somewhat different procedure, damping-off everywhere can be controlled by proper disinfection of the seed beds. The economic results at all of these nurseries are briefly described in the following pages, together with a summary of the published results of other investigators.

\section{RESULTS OF SOIL DISINFECTION AT NURSERIES WHERE REPEATED TESTS HAVE BEEN} MADE.

The first tests were made in pine seed beds in the very sandy soil of the United States Forest Service nursery at Halsey, Nebr. The experience at this nursery was in many ways typical and will therefore be described in some detail.

The first attempt was to control the disease by applying disinfectants after the seedlings appeared above ground. This failed, partly because the disinfectants injured the seedlings and partly because the parasites were found to do a great deal of their work before the seedlings came up. A number of disinfectants were then tested in applications at or before seed sowing. Of these, commercial sulphuric acid appeared the cheapest and most effective. Both heat and formaldehyde, the means usually recommended for disinfecting greenhouse and truck soils, proved less reliable as well as more expensive. 
The treatment finally adopted consists of three-sixteenths fluid ounce of sulphuric acid per square foot of seed bed, applied in solution immediately after the seed is sown and covered. The amount of water used to dissolve the acid varies from 1 pint per square foot when the soil is wet to 2 pints when the soil is dry. In all disinfection of seed beds by chemicals the quantity of the disinfectant used per unit area of soil surface seems to be the important variable. The disinfectant must be dissolved in sufficient water to permit its distribution through the soil to a depth of several inches, but within certain limits the concentration of the solution as applied does not appear to be an important factor. The adherence of some investigators to the concentration of the solution used as a measure of soil treatment makes their work difficult to correlate.

In the earlier tests of acid at Halsey chemical injury to the pines occurred in beds treated with acid at the time of sowing. It was found that dormant pine seeds were not injured by acid, but that the root tips of the seedlings in acid beds were often killed just after germination commenced. The way in which this injury occurred made it evident that it was due to the concentration of the acid in the surface soil. Evaporation of water from the soil surface seemed to bring up the disinfectant from the lower soil, just as alkali salts come to the surface in alkali soils. Watering the beds frequently during the germinating period prevents such surface concentration and in practice has been found entirely to prevent injury to the seedlings. The method of protecting the seedlings from acid injury at this nursery is to water the seed beds frequently from the time seed is sown until a few days after germination, when the root tips have penetrated one-half inch into the soil. After this time they are practically safe from further injury. The beds are watered daily in ordinary spring weather, every other day in misty or rainy weather, and twice daily when the maximum temperature exceeds $80^{\circ} \mathrm{F}$. In clear weather each watering is at the rate of approximately $1 \frac{1}{2}$ pints per square foot of bed. In cold, cloudy weather 1 pint per square foot is found sufficient. (Two-tenths inch of rainfall is equivalent to 1 pint per square foot.)

The acid treatment was repeatedly tested on different species of pine during different years and at different times of the year. In all cases it resulted in increased stands. The results of all the acid tests in which the above watering system or its equivalent was followed are given in Table I.

In addition to the three species given in this table, a test on a series of plats of Corsican pine (Pinus laricio Poir.) gave excellent results; an accident prevented the securing of exact figures. Some of the tests included in the table were conducted on a considerable scale, the total area involved being 8,350 square feet in the treated 
plats and 547 feet in the untreated plats. In the case of the larger plats, counts of seedlings were made only on sample areas scattered through the plats. The percentages of germination and of death are based on counts of all seedlings on 246 square feet in the treated plats and 145 square feet in the untreated plats. The surviving seedlings were counted on these sample areas and also on additional areas, totaling 406 square feet for the acid plats and 196 square feet for the untreated plats. Damping-off is so variable that only repeated and extensive tests of this sort are entirely reliable.

TABLE I.-Control of damping-off of pines by three-sixteenths fluid ounce of sulphuric acid per square foot of seed bed applied at sowing time, Halsey, Nebr.

\begin{tabular}{|c|c|c|c|c|c|c|c|c|}
\hline \multirow{2}{*}{ Species. } & \multirow[b]{2}{*}{$\begin{array}{l}\text { Number } \\
\text { of sepa- } \\
\text { rate tests. }\end{array}$} & \multirow[b]{2}{*}{$\begin{array}{l}\text { Treat- } \\
\text { ment. }\end{array}$} & \multicolumn{3}{|c|}{ Absolute results. } & \multicolumn{3}{|c|}{ Relative results. } \\
\hline & & & $\begin{array}{c}\text { Germina- } \\
\text { tion. } 1\end{array}$ & $\begin{array}{l}\text { Death } \\
\text { per hun- } \\
\text { dred seed- } \\
\text { lings.2 }\end{array}$ & $\begin{array}{c}\text { Final } \\
\text { stand } \\
\text { based on } \\
\text { seedsown. }\end{array}$ & $\begin{array}{c}\text { Germina- } \\
\text { tion. }\end{array}$ & Death. & $\begin{array}{l}\text { Final } \\
\text { stand. }\end{array}$ \\
\hline $\begin{array}{l}\text { Pinus banksiana }{ }^{3} \ldots \\
\text { P. ponderosa........ } \\
\text { P. resinosa.......... }\end{array}$ & \begin{tabular}{r|}
11 \\
3 \\
3
\end{tabular} & $\begin{array}{l}\text { Acid.... } \\
\text { None... } \\
\text { Acid.... } \\
\text { None... } \\
\text { Acid.... } \\
\text { None.... }\end{array}$ & $\begin{array}{r}\text { Per cent. } \\
32.7 \\
20.3 \\
66.3 \\
50.3 \\
70.0 \\
62.7\end{array}$ & $\begin{array}{l}15.2 \\
43.7 \\
12.0 \\
36.7 \\
38.7 \\
73.7\end{array}$ & $\begin{array}{r}\text { Per cent. } \\
26.4 \\
9.9 \\
58.7 \\
33.0 \\
40.7 \\
16.0\end{array}$ & $\begin{array}{l}161 \\
100 \\
132 \\
100 \\
112 \\
100\end{array}$ & $\begin{array}{r}35 \\
100 \\
33 \\
190 \\
53 \\
100\end{array}$ & $\begin{array}{l}267 \\
100 \\
178 \\
100 \\
254 \\
100\end{array}$ \\
\hline Average ${ }^{3} . . . .$. . & 17 & $\begin{array}{l}\text { Acid.... } \\
\text { None... }\end{array}$ & $\begin{array}{l}56.3 \\
44.4\end{array}$ & $\begin{array}{l}22.0 \\
51.4\end{array}$ & $\begin{array}{l}41.9 \\
16.3\end{array}$ & $\begin{array}{l}135 \\
100\end{array}$ & $\begin{array}{r}43 \\
100\end{array}$ & $\begin{array}{l}233 \\
100\end{array}$ \\
\hline
\end{tabular}

1 The germination percentage takes into account only seedlings which appear above the soil. Seeds which started to germinate but did not reach the point of breaking through tho soil are not included.

2 The death percentage includes all seedlings which died from damping-off and also any which may have died from drought or chemical injury after the seedlings eame up. Seedlings broken by hail or other mechanical means or killed by insects are not included.

${ }^{3}$ Germination and death figures obcained from only 9 of the 11 jack-pine tests.

The acid in practically all cases caused a marked increase in the number of seedlings that came up, as well as a decrease in the death rate after coming up. Damping-off was not entirely controlled. There was still a loss of 22 per cent after germination in the treated plats, but the loss in the untreated plats was nearly two and one-half times as great. The combined effect of increased germination and decreased death rate was a large increase in the number of healthy seedlings produced. (See Table I, columns headed "Final stand.")

It is especially to be noted that in jack pine and Norway pine, the species with which the most extensive tests were made, more than 250 healthy seedlings were obtained in the treated plats for every 100 obtained from equal quantities of seed in the untreated plats. The results of the acid treatment of Norway pine are strikingly shown by the difference in stand in the treated and untreated plats shown in Plate I, figure 1.

Since the foregoing tests were conducted, the acid treatment has been put into regular use on all spring-sown beds at this nursery and the success of the treatment further confirmed by the continued good results secured. 


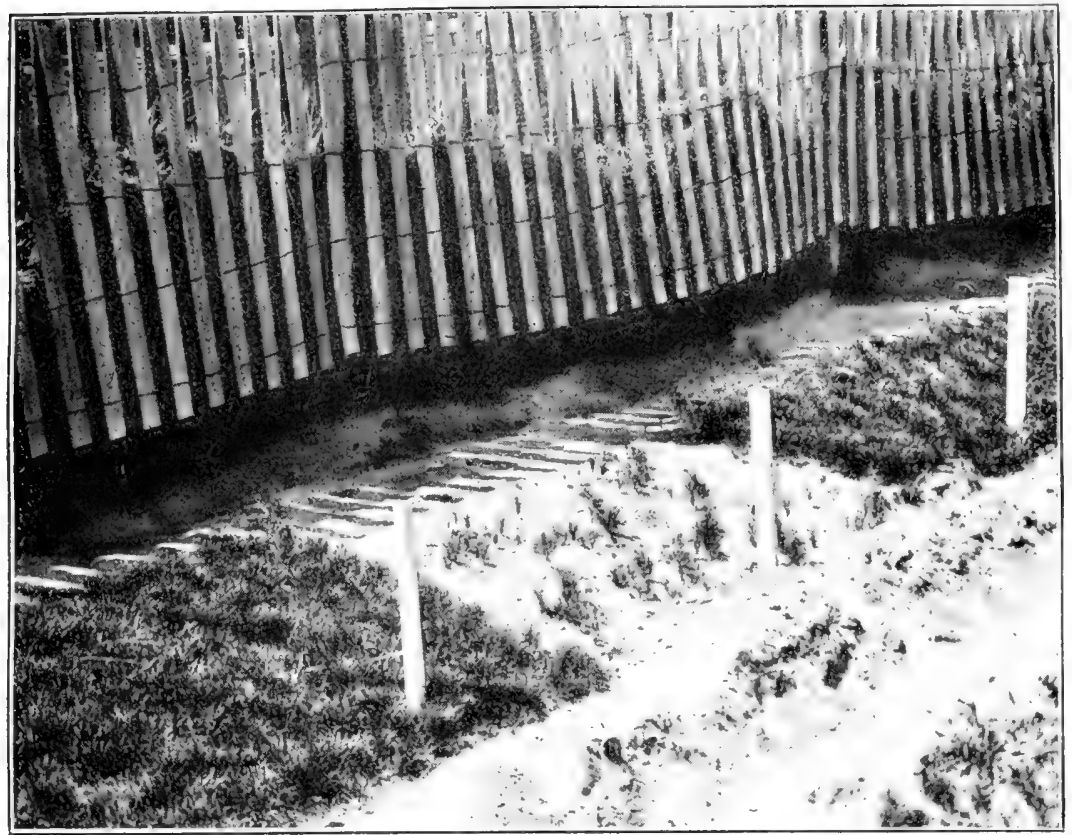

Fig. 1.-Norway-Pine Seed Bed, 1 Year Old, Halsey, Nebr.

Plat in center untreated Remainder of bed treated at time of sowing with a solution containing three-sixteent hs fluid ounce of sulphuric acid per square foot of bed. Practically all of the seedlings in the untreated plat have been destroyed by damping-ofi. L'hotographed by Charles B. P'ool ( $\mathrm{F} 1$ ).

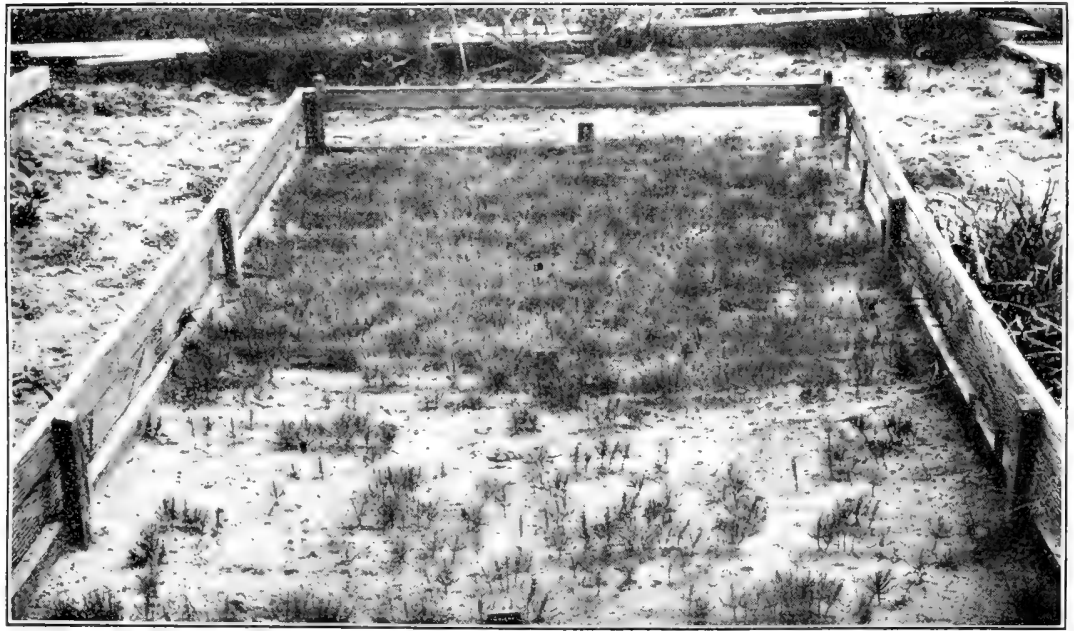

Fig. 2.-Western Yellow-Pine Seed Bed, Kansas Sandhills.

Foreground untreated. Background treated at time of sowing with a sulphurie-acid solution. Mnst of the seedlings in the untreated plat have been destroyed by damping-off. P'hotographed by I)r. 


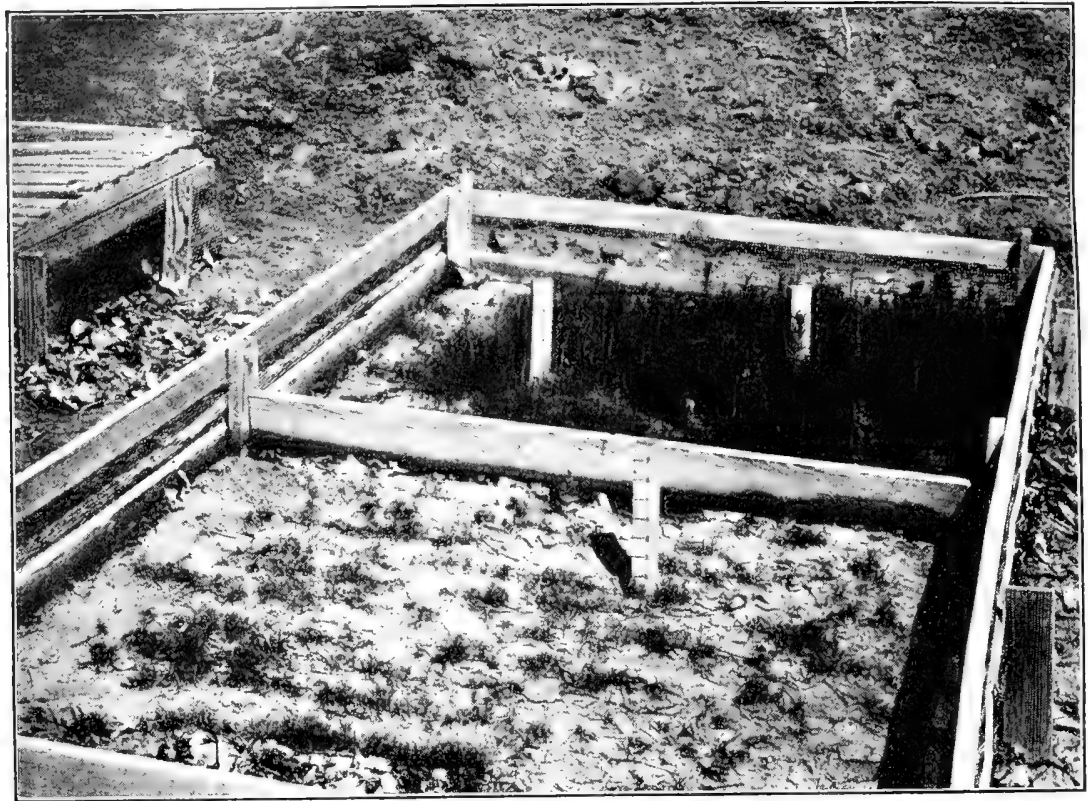

Fig. 1.-Jack-Pine Seed Bed, Garden City, Kans.

Foreground untreated. Background treated with sulphuric-acid solution before germination. Stakes marked in inches. Note the difference in height of the seedlings after the first season's growth ( F 3).

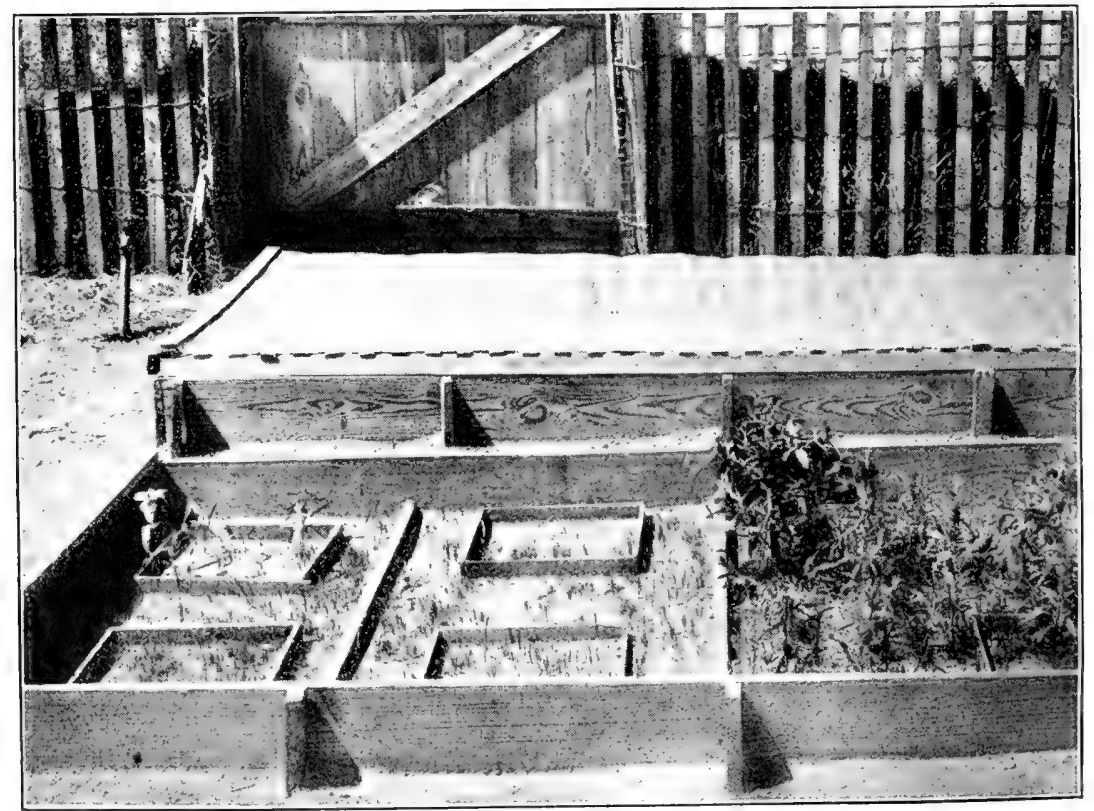

Fig. 2.-Jack-PIne Seed Bed, Kansas SANDHILls.

Plat at left treated with one-fourth ounce and plat at center with three-eighths ounce of sulphuric acid per square foot. Plat at right untreated. Note the relative freedom from weeds in the treated plats. The apparently thin stand of trees in the treated plats is due to the very small size of the young seedlings of this species of pine. Actual counts in these plats showed the stand to of the young seedngs of this species of pine, Act overcrowding. Photographed by Stephen C. Bruner $(\mathrm{F} 4)$. 
At nearly all of the other nurseries sulphuric acid was also found successful in controlling damping-off. However, because of differences in soil and climate, the treatments required elsewhere differed in some details from that at Halsey. On a still lighter sand in Kansas sand hills, which was probably also somewhat more alkaline, it was found that damping-off could be controlled best by a hearier treatment of acid-one-fourth fluid ounce per square foot in ordinary spring-sown beds, and five-sixteenths or three-eighths ounce in beds sown in the fall or very early spring. The watering required during the germinating period to prevent injury to the pines was less than at Halsey. The losses in untreated beds at this nursery were exceptionally heavy. In the treated beds it was not possible to reduce the damping-off loss to as low a figure as at Halsey, probably because of the common occurrence of Fusarium moniliforme, a fungus exceptionally able to quickly reinfect treated beds. The success of the treatment from the economic standpoint, however, was greater than at Halsey. Without the treatment, failure occurred in the seed beds more often than success, and stock could not be raised at a reasonable expense. With the treatment, success was the rule, and the economical production of stock became possible. The difference in stand between treated and untreated plats at this nursery is shown in Plate I, figure 2.

At a single nursery on a fine sandy soil near Morrisville, Pa., it was found that it was more difficult than at Halsey to prevent acid injury to germinating seedlings. This was a nursery at which tests were made during a single season only. It is mentioned at this point merely to show the difference in behavior of acid in different soils. Even onetwelfth fluid ounce per square foot caused injury to the pines at Morrisville. Indications from the small series of tests conducted there were that one-eighth ounce of acid per square foot would probably prove effective against damping-off and harmless to coniferous seedlings if followed by sufficiently frequent watering during the germinating period. It is likely that this soil was slightly acid to start with.

In marked contrast to the experience at Morrisville are the results obtained at Fort Bayard, N. Mex., Monument, Colo., and Haugan, Mont. At all of these places acid at the rate of three-sixteenths ounce or more per square foot has been applied to the beds at sowing in repeated tests, without any injury to the seedlings that could be detected by the forest officers in charge at the nurseries. At Fort Bayard Mr. H. C. Turner has tested the acid very thoroughly for four successive seasons and in quantities up to five-eighths ounce per square foot without finding any injury to seedlings. Even three-sixteenths ounce proved reasonably efficient in decreasing damping-off, and the five-eighths ounce treatment reduced the loss to less than 1 per cent.

$60142^{\circ}-$ Bull. $458-17-2$ 
At Haugan the acid has been used for three years and damping-off has been practically abolished in the beds treated. These three nurseries differ from the preceding three in that the soil is heavier and there is no need of any extra watering in order to prevent chemical injury to the seedlings.

At a seventh nursery an entirely different condition was encountered. The seed beds were located on a rather heavy soil near Garden City, Kans. This soil effervesced vigorously when treated with acid, yielding 0.23 per cent of carbon dioxid from the surface soil and over 1 per cent from the subsoil in a test made by the Bureau of Soils. Acid treatments had no effect on damping-off in this soil; owing presumably to the high carbonate content and consequent alkalinity which the effervescence indicated. Tests with copper sulphate, one-fourth ounce per square foot, and zinc chlorid, one-half ounce per square foot, showed that both these and heavier treatments were effective against damping-off. The results are given in Table II.

TABLE II.-Control of damping-off of pines by one-fourth to three-fourths ounce copper sulphate and one-half to one ounce zinc chlorid per square foot of seed bed, Garden City, Kans.

\begin{tabular}{|c|c|c|c|c|c|c|c|c|}
\hline \multirow[b]{2}{*}{ Species and time of sowing. } & \multirow[b]{2}{*}{ Disinfectant. } & \multirow{2}{*}{$\begin{array}{l}\text { Num- } \\
\text { ber of } \\
\text { sepa- } \\
\text { rate } \\
\text { tests. }\end{array}$} & \multicolumn{3}{|c|}{ Absolute results. } & \multicolumn{3}{|c|}{ Relative results. } \\
\hline & & & $\begin{array}{l}\text { Ger- } \\
\text { mina- } \\
\text { tion. }\end{array}$ & $\begin{array}{c}\text { Death } \\
\text { per hun- } \\
\text { dred } \\
\text { seed- } \\
\text { lings. }\end{array}$ & $\begin{array}{c}\text { Final } \\
\text { stand } \\
\text { based } \\
\text { on seed } \\
\text { sown. }\end{array}$ & $\begin{array}{c}\text { Ger- } \\
\text { mina- } \\
\text { tion. }\end{array}$ & Death. & $\begin{array}{l}\text { Final } \\
\text { stand. }\end{array}$ \\
\hline Pinus anstriaca: … & $\left\{\begin{array}{l}\text { Copper sulpbate... } \\
\text { None................ }\end{array}\right.$ & 2 & $\left\{\begin{array}{l}\text { Perct. } \\
40.1 \\
15.8\end{array}\right.$ & $\begin{array}{l}59.0 \\
91.0\end{array}$ & $\begin{array}{r}\text { Perct. } \\
21.3 \\
1.3\end{array}$ & $\begin{array}{l}254 \\
100\end{array}$ & $\begin{array}{r}65 \\
100\end{array}$ & $\begin{array}{r}1,638 \\
100\end{array}$ \\
\hline SI & $\left\{\begin{array}{l}\text { Zine chlorid.......... } \\
\text { None............... }\end{array}\right.$ & \}$=1$ & $\left\{\begin{array}{l}37.5 \\
19.5\end{array}\right.$ & $\begin{array}{r}99.0 \\
100.0\end{array}$ & $0^{.5}$ & $\begin{array}{l}192 \\
100\end{array}$ & $\begin{array}{r}99 \\
100\end{array}$ & $\begin{array}{l}(a) \\
(a)\end{array}$ \\
\hline P. ban & $\left\{\begin{array}{l}\text { Copper sulphate.... } \\
\text { None................ }\end{array}\right.$ & 3 & $\left\{\begin{array}{l}27.1 \\
25.9\end{array}\right.$ & $\begin{array}{l}35.2 \\
62.3\end{array}$ & $\begin{array}{r}16.1 \\
7.6\end{array}$ & $\begin{array}{l}105 \\
100\end{array}$ & $\begin{array}{r}56 \\
100\end{array}$ & $\begin{array}{l}212 \\
100\end{array}$ \\
\hline & $\left\{\begin{array}{l}\text { Zine chlorid ......... } \\
\text { None.............. }\end{array}\right.$ & 3 & $\left\{\begin{array}{l}30.7 \\
23.7\end{array}\right.$ & $\begin{array}{l}27.6 \\
69.0\end{array}$ & $\begin{array}{r}21.0 \\
5.8\end{array}$ & $\begin{array}{l}130 \\
100\end{array}$ & $\begin{array}{r}40 \\
100\end{array}$ & $\begin{array}{l}362 \\
100\end{array}$ \\
\hline Spring & $\left(\begin{array}{l}\text { Copper sulphate... } \\
\text { None.................. }\end{array}\right)$ & 2 & $\left\{\begin{array}{l}16.6 \\
11.6\end{array}\right.$ & $\begin{array}{l}67.8 \\
67.0\end{array}$ & $\begin{array}{r}19.0 \\
6.3\end{array}$ & $\begin{array}{l}143 \\
100\end{array}$ & $\begin{array}{l}101 \\
100\end{array}$ & $\begin{array}{l}143 \\
100\end{array}$ \\
\hline spring - & $\left|\begin{array}{l}\text { Zine chlorid......... } \\
\text { None............... }\end{array}\right|$ & ${ }^{*} 2$ & $\left\{\begin{array}{l}37.5 \\
14.2\end{array}\right.$ & $\begin{array}{l}20.0 \\
66.0\end{array}$ & $\begin{array}{r}28.9 \\
6.4\end{array}$ & $\begin{array}{l}264 \\
100\end{array}$ & $\begin{array}{r}30 \\
100\end{array}$ & $\begin{array}{l}452 \\
100\end{array}$ \\
\hline A verage, fall and spring.. & $\left\{\begin{array}{l}\text { Copper sulphate } \\
\text { and zinc chlorid. } \\
\text { None................... }\end{array}\right.$ & & $\begin{array}{l}28.0 \\
18.9\end{array}$ & $\begin{array}{l}37.7 \\
66.1\end{array}$ & $\begin{array}{r}18.8 \\
6.5\end{array}$ & $\begin{array}{l}148 \\
100\end{array}$ & $\begin{array}{r}57 \\
100\end{array}$ & $\begin{array}{l}289 \\
100\end{array}$ \\
\hline P. ponderosa: & $\left(\begin{array}{l}\text { Copper sulphate } \\
\text { None................ }\end{array}\right.$ & 2 & $\left\{\begin{array}{l}46.1 \\
40.9\end{array}\right.$ & $\begin{array}{l}20.1 \\
59.8\end{array}$ & $\begin{array}{l}34.8 \\
16.0\end{array}$ & $\begin{array}{l}113 \\
100\end{array}$ & $\begin{array}{r}34 \\
100\end{array}$ & $\begin{array}{l}217 \\
100\end{array}$ \\
\hline & $\left\{\begin{array}{l}\text { Zinc chlorid.......... } \\
\text { None.............. }\end{array}\right.$ & 2 & $\left\{\begin{array}{l}42.9 \\
36.6\end{array}\right.$ & $\begin{array}{l}16.1 \\
57.4\end{array}$ & $\begin{array}{l}33.1 \\
18,1\end{array}$ & $\begin{array}{l}117 \\
100\end{array}$ & $\begin{array}{r}28 \\
100\end{array}$ & $\begin{array}{l}183 \\
100\end{array}$ \\
\hline Spring... & $\left(\begin{array}{l}\text { Copper sulphate... } \\
\text { None.................. }\end{array}\right)$ & 8 & $\left\{\begin{array}{l}58.1 \\
50.9\end{array}\right.$ & $\begin{array}{l}24.0 \\
45.1\end{array}$ & $\begin{array}{l}42.2 \\
28.7\end{array}$ & $\begin{array}{l}114 \\
100\end{array}$ & $\begin{array}{r}53 \\
100\end{array}$ & $\begin{array}{l}147 \\
100\end{array}$ \\
\hline & 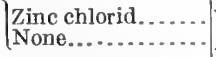 & 6. & $\left\{\begin{array}{l}61.3 \\
52.7\end{array}\right.$ & $\begin{array}{l}b 11.8 \\
b 39.1\end{array}$ & $\begin{array}{l}46.6 \\
31.0\end{array}$ & $\begin{array}{l}116 \\
100\end{array}$ & $\begin{array}{r}30 \\
100\end{array}$ & $\begin{array}{l}150 \\
100\end{array}$ \\
\hline Average, fall and spring.. & $\left\{\begin{array}{c}\text { Zine chlorid and } \\
\text { copper sulphate. } \\
\text { None................... }\end{array}\right.$ & & $\begin{array}{l}52.1 \\
45.3\end{array}$ & $\begin{array}{l}18.0 \\
50.4\end{array}$ & $\begin{array}{l}39.2 \\
23.5\end{array}$ & $\begin{array}{l}115 \\
100\end{array}$ & $\begin{array}{r}36 \\
100\end{array}$ & $\begin{array}{l}167 \\
100\end{array}$ \\
\hline
\end{tabular}

$a$ No expression possible. $\quad b$ The damping-off percentage was determined in but five of the six tests. 
Copper sulphato could probably have been used with success in quantities less than one-fourth ounce per square foot. A three-eighths ounce zinc-chlorid treatment proved unsuccessful. Both disinfectants were dissolved in water and applied in most cases just aftor seed sowing, as was done with acid. Both were found harmless to the dormant seed in these concentrations, but both were capable of injuring germinating seedlings in just the same way as is described for acid at Halsey. This injury was prevented by extra watering during the germinating period, in the same way as acid injury was prevented at the Halsey and Kansas sand-hill nurseries. The amount of this extra watering needed at the Garden City nursery was very slight.

An interesting thing that developed at this nursery, as well as at the Kansas sand-hill nursery, was the control of spring damping-off by treatments applied during November of the preceding year. Part of the fall-sown plats whose results were shown in Table II were treated at the time of sowing and part as soon as the soil thawed the following spring. Though the seedlings did not appear until the following April, disinfectants applied in November seemed to protect them from damping-of: as well, or practically as well, as disinfectants applied in March. At this nursery and at the five preceding at which repeated tests were made, the treatments developed have been put into regular large-scale use by the nurserymen, with good results.

RESULTS OF SOIL DISINFECTION AT NURSERIES WHERE TESTS HAVE LEEN LIMITED TO A SINGLE SEASON.

At Porvenir, N. Mex., Dundee, Ill., Lincoln, Nebr., the nursery of the State Board of Forestry in Vilas County, Wis., and the greenhouses of the United States Department of Agriculture at Washington, D. C., single-season tests of sulphurie acid have given good results. At all of these places no need was found for any special watering provision for the prevention of chemical injury from the acid. The tests at Dundee and Lincoln were made during an unusually rainy season. It may devclop that in years with less rain more watering will be needed at these places.

At four other nurseries where disinfectants were tested in this preliminary way the results were less definite. At Morrisville, Pa., already referred to, there was distinct evidence that a very weak acid treatment with sufficient watering during the germinating period will be entirely successful in controlling the small amount of damping-off which normally occurs there. One-eighth ounce of acid per square foot it is thought will be sufficient. Insufficient watering prevented the securing of exact information from the tests conducted. At Pocatello, Idaho, a single test of acid on beds of Douglas fir had no conspicuous effect on the amount of damping-off. As the soil is found to effervesce on the addition of acid, success with acid does not 
appear probable. At Cass Lake, Minn., acid was tested on seed beds of Norway pine (Pinus resinosa) during a period of weather so abnormally cold and wet that the seed lay in the ground for a number of weeks before germination was completed. Under these conditions, for the first time in the writers' experience, the acid treatment of the beds at the time of sowing resulted in decreased germination. No special watering was needed to prevent injury to the tips after the seedlings began to come up; in fact, very frequent watering given one bed resulted in less germination and therefore poorer results than in acid beds with no extra watering. Despite the decrease in germination, the acid beds, because of the almost complete control of dampingoff by the treatment, finished the season with an average of 135 seedlings for every 100 in the untreated plats, and the acid plats which were not given excessive water had 151 seedlings for every 100 in the untreated plats. This fact and the fact that acid beds which had first been treated with lime and were thereby kept from injury to the secd produced 228 seedlings for every 100 in the untreated plats indicate that in ordinary seasons the treatment with acid alone will be entirely successful. The use of lime with acid is usually undesirable because by neutralizing the acid it permits the parasites to resume work soon after treatment. Formaldehyde gave better results than acid at Cass Lake. While it is thought that this would not be the case in a normal season, it is evident that further tests are needed to determine what treatment to use.

The danger in drawing conclusions from the results of three or four test plats is shown especially well by the results obtained by Prof. H. H. York, of Brown University, in testing treatments recommended by the writers. Treatments involving five-sixteenths ounce of sulphurio acid, five-eighth ounce of zine chlorid, and $2 \frac{1}{2}$ ounces of cane sugar, respectively, per square foot of bed, resulted in final stands from $4 \frac{1}{2}$ to 15 times as dense as in most of the untreated plats. One untreated plat, however, gave a stand as dense as that on the treated plats. This throws doubt on the reliability of the results on the other plats and indicates that only repeated tests, each with plenty of untreated plats for abundant comparison, are reliable enough to be used as a basis for conclusions.

At several of the nurseries mentioned above other soil treatments were tried with success. At Glenview, Ill., where acid failed, coppersulphate treatment resulted in doubling the final stand. The good results obtained on otherwise untreated soil at Dundee, Ill., by the addition of cane sugar were rather surprising; indications of damping-off control by sugar were also observed at Garden City, Kans., East Tawas, Mich., and Providence, R. I. Further tests are required. At East Tawas, a test of acid in an unfavorable season did not give as good results as desired, while formaldehyde resulted in a doubled stand. 


\section{RESULTS OF SOIL DISINFECTION IN GREENHOUSE TESTS.}

In the greenhouses of the Department of Agriculture at Washington, D. C., disinfection of soil by steam pressure has proved reasonably effective in controlling damping-off of pine seedlings in most of a rather large number of tests conducted during the winter months. During the summer there is so much reinfection that the results of heat disinfection are uncertain. A single test of sulphuric acid in the spring of 1915 indicated the value of acid treatment in reducing damping-off in the greenhouse. Four flats of jack pine were treated with sulphuric acid in quantities of three-sixteenths to three-cighths ounce per square foot just after sowing. - The relative survival in the acid flats, taking the average survival in the untreated flats as 100 , was 128. The relative survival in flats disinfected by steam was only 105. Three-sixteenths ounce of acid per square foot gave as good results as heavier treatments. The soil used in this experiment was a mixture of seven parts loam, four parts sand, two parts manure, and one part leaf mold.

\section{RESULTS IN DISINFECTING THE SOIL OBTAINED BY OTHER INVESTIGATORS.}

Spaulding, ${ }^{1}$ who appears to have been the originator of the use of sulphuric acid for soil disinfection, has tested acid and other disinfectants at several places. In greenhouse tests formaldehyde and copper sulphate were found valuable, but the sulphate injured seedlings. At Saranac Inn, N. Y., formaldehyde apparently increased damping-off one season and controlled it in a later season, while sulphuric acid injured seedlings and gave results which from the economic standpoint were inconclusive.

At Burlington, Vt., results with disinfectants in pine-seed beds have been reported by Spaulding, ${ }^{2}$ Jones, ${ }^{3}$ Gifford, ${ }^{4}$ and Burns. ${ }^{5}$ Formaldehyde applied five days before sowing and allowed to evaporate for two days before sowing killed part of the seed. All of the writers found formaldehyde of decided value in controlling damping-off. Jones and Spaulding report a single test in which but one-tenth ounce (0.106 ounce) of formaldehyde was used per square foot and excellent results obtained. The subsequent tests reported have been with amounts of 0.48 ounce or over per square foot. The treatment used by Burns, of 0.58 ounce of formaldehyde per square foot, applied

1 Spaulding, Perley. The damping-off of coniferous seedlings. In Phytopathology, v. 4, no. 2, p. 73-88, 2 fig., pl. 6. 1914.

- The treatment of damping-off in coniferous seedlings. U. S. Depl. $\Lambda$ gr., Bur. Plant Indus. Circ. 4, 8 p. 1908.

2 Spaulding, Perley, 1914. Op. cit.

3 Jones, L. R. The damping-ofi of coniferous seedlings. In Vt. Agr. Exp. Sta. 20th Ann. Rpt., 1906-7, p. 342-347. 1908.

4 Gifford, C. M. The damping-off of coniferous seedlings. Vt. Agr. Exp. Sta. Bul. 157, p. 141-171, 10 fig., $4 \mathrm{pl}, 1911$.

${ }_{5}^{5}$ Burns, G. P. Studies in tolerance of New England forest trees. I. Development of white pine seedlings in nursery beds. Vt. Agr. Exp. Sta. Bul. 178, p. 125-144, 2 fig., 4 pl. 1914. 
11 days before sowing, with the beds tightly covered during the interim, appears to have been entirely harmless and very effective against the disease. Burns found the sulphuric-acid treatment used by the writers at Halsey, three-sixteenths ounce per square foot applied at time of sowing, as effective as the formaldehyde and noninjurious. Spaulding, ${ }^{1}$ reporting tests made in 1907 and 1908, also obtained excellent results with acid, which was not tested by Jones and Gifford. He in addition obtained good results in preliminary tests with copper sulphate and with sulphur.

Acid was also used at an unnamed locality by Güssow, ${ }^{2}$ with excellent results.

Charcoal, an amendment rather than a disinfectant, is reported by Retan $^{3}$ to be of value against damping-off in the clay soil at. Mont Alto, Pa., and to result in the increased size of pine seedlings. A layer 3 inches deep was spaded into the soil. Annual treatment with this amount would, of course, be impracticable. However, Retan states that the effect of such charcoal addition is permanent. Further experience seems necessary to confirm the permanent value of charcoal for preventing damping-off on this and other soils. A single test by the writers of a lighter application of charcoal at the Cass Lake nursery proved unsuccessful.

\section{SOIL-DISINEECTION TESTS SUMMARIZED.}

The writers' experience with soil disinfectants at the different nurseries, as well as the experience of other experimenters, has been so varied that it is rather difficult to correlate the results. Correlation will be made easier by. reference to Table III, in which are summed up ail of the successful tests of treatments of coniferous seed beds of which the writers have been able to learn. In the tests at Halsey, the Kinsas sand hills, Garden City, Lincoln, Cass Lake, Dundee, Glenview, and East Tawas, the experimental treatments were applied by the writers or their assistants, with the cooperation of those in charge of the nurseries. At Fort Bayard the tests were conducted by Mr. H. C. Turner, at Monument by Mr. W. H. Schrader, at Porvenir by Mr. H. D. Burrall, at Pocatello by Mr. Arthur P. Say, in Vilas County, Wis., by Mr. W. D. Barnard, at Providence by Prof. H. H. York, at Morrisville under the direction of Mr. John Folcy, and at Haugan by forest officers, following recommendations made by the writers.

\footnotetext{
1 Spaulding, Perley, 1914. Op. cit.

${ }^{2}$ Güssow, H. T. Diseases of forest trees. In Com. Conserv. Canada, Rpt. 1st Ann. Meeting, 1910, p. 136-137. 1910.

${ }_{3}$ Retan, G. A. Charcoal as a means of solving some nursery problems. In Forestry Quart., v. 13, no. 1, p. $25-30.1915$.
} 
DAMPING-OFF OF CONIFEROUS SEEDLINGS.

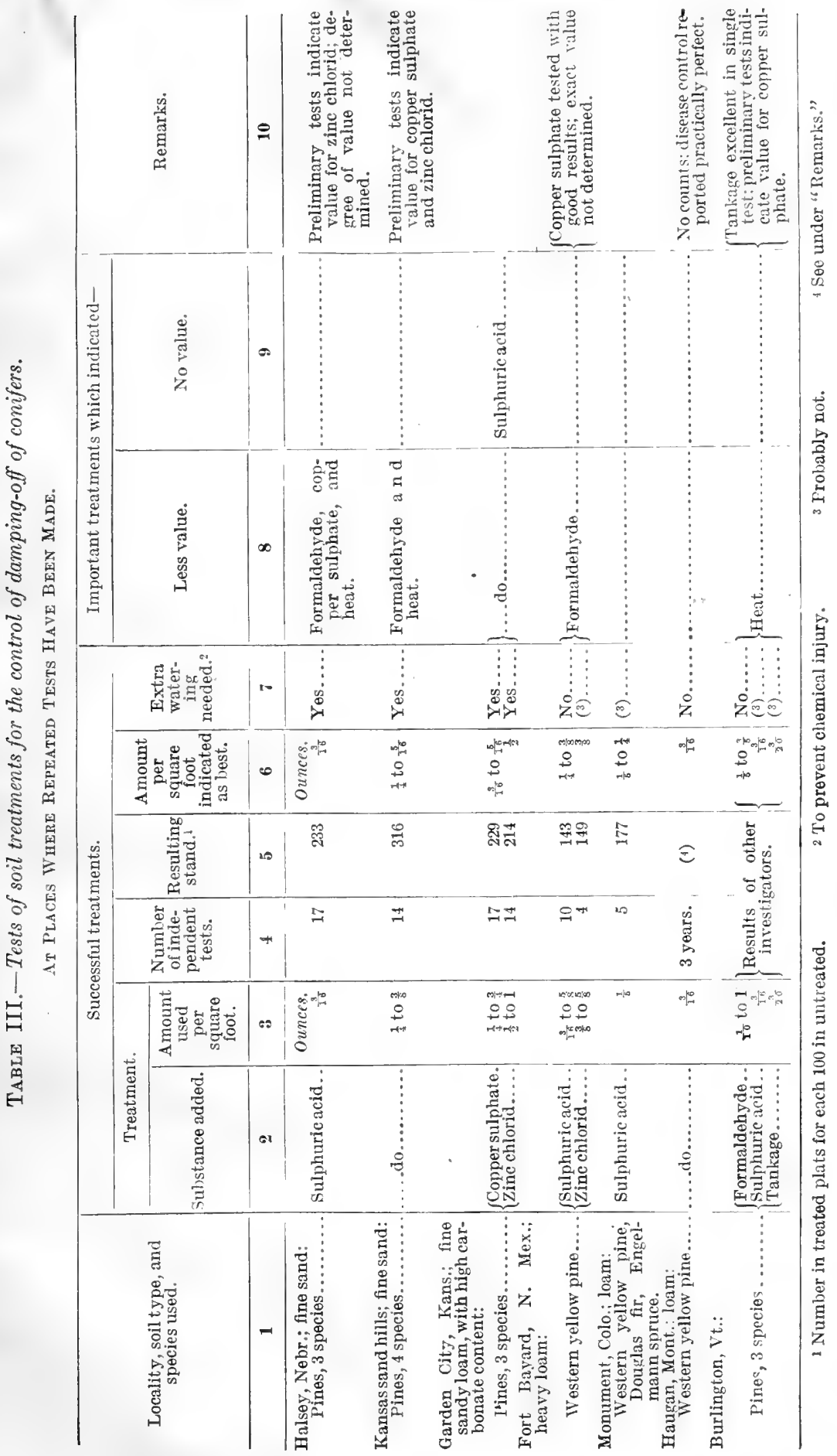



BUlletin 453, U. S. DepartMent OF AGRICUlture.

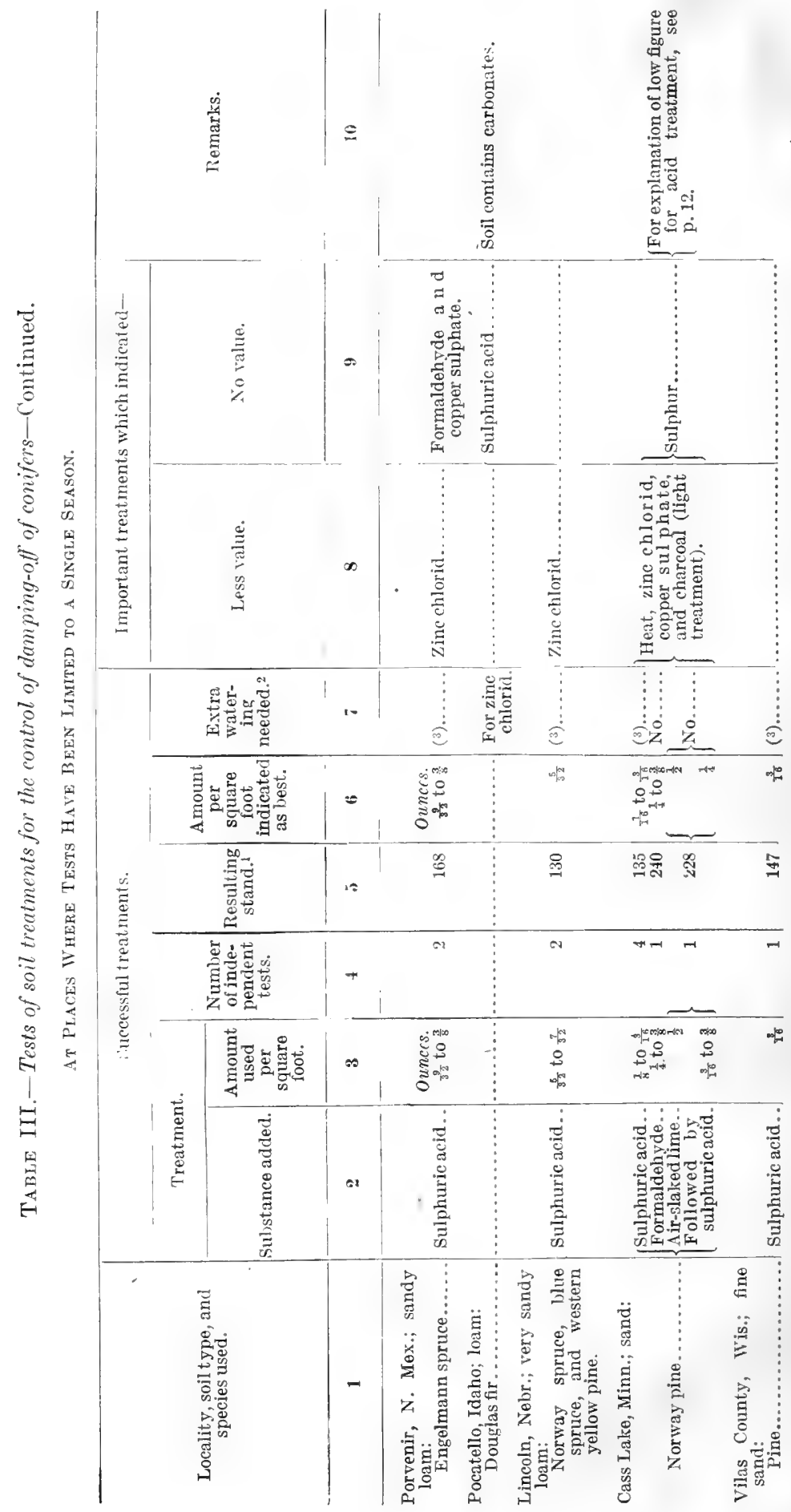


DAMPING-OFF OF CONIFEROUS SEEDLINGS.

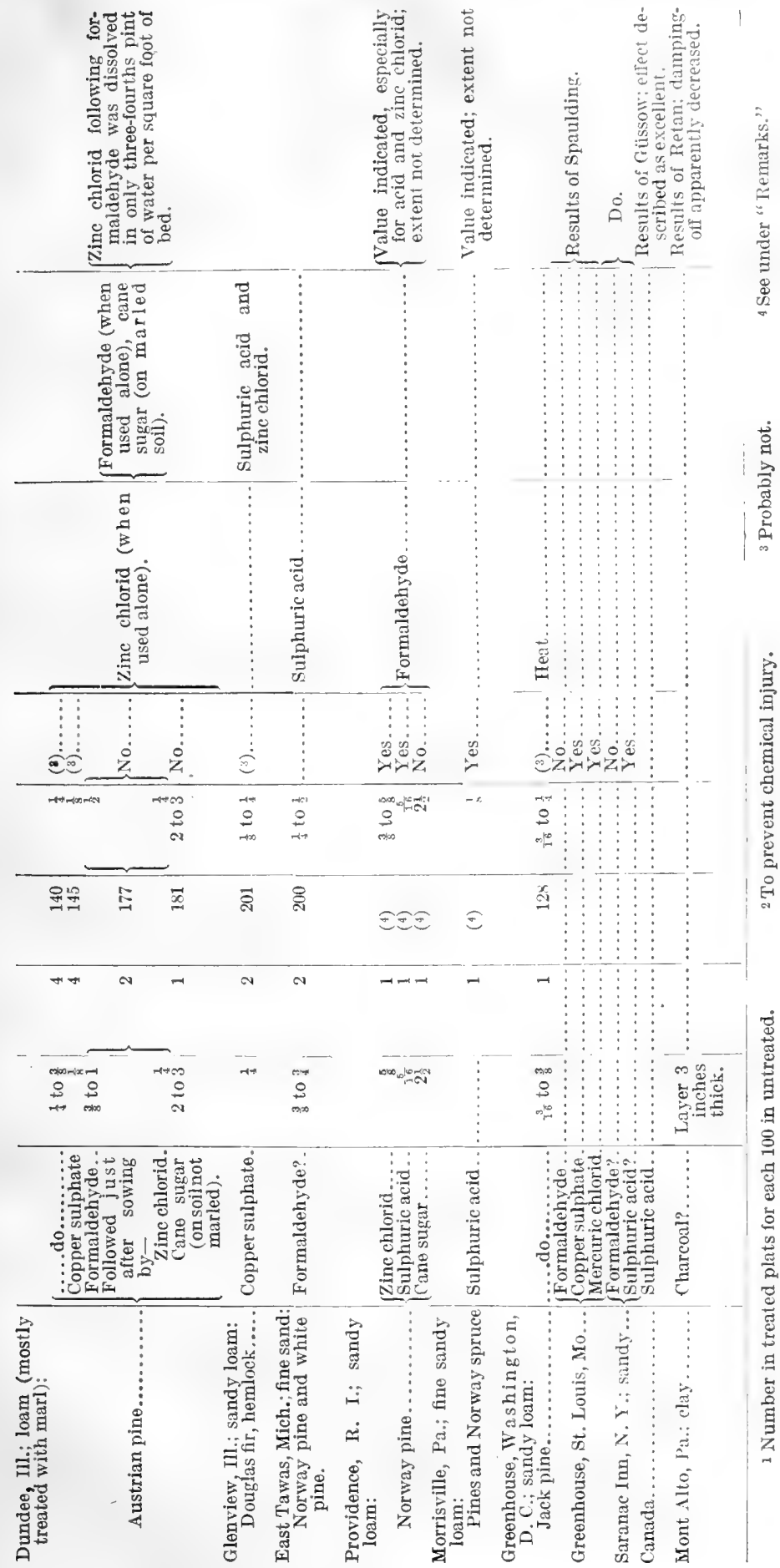


In most of the treatments listed in Table III the substance used was applied just after the seed was sown and covered. Formaldehyde kills some of the seed if so used and was accordingly applied several days before seed sowing. Either the soil was treated a week or more before sowing in the formaldehyde plats and kept covered with heavy paper for a few days after treatment, or else the treatment was made but two or three days hefore sowing and no paper was used. Even with these precautions part of the seed was killed in the tests at Burlington, the Kansas sand hills, and Glenview. Zinc ohlorid killed the dormant jack-pine seed in two heavily treated plats at Garden City which were sown and treated in the fall and remained dormant throughout the winter. It ordinarily produces no such effect. Sulphurio acid has also shown a tendenoy to decrease the germination percentage in two or three tests of fall treatments, but ordinarily has no such effect in spring-sown beds. It has never had more than a slight delaying effeot on germination except during very wet, cold weather, and its harmful effect on dormant seed in spring-sown beds is negligible. Copper sulphate shows even less tendency than sulphuric acid to injure dormant seed. Sulphuric acid, copper sulphate, and zino chlorid are all inclined in some soils to injure the root tips of seedlings just after germination begins; on such soils the injury to seedlings can be prevented by very frequent watering during the germinating period. Column 7 of Table III indieates for the best strength of each successful treatment whether or not such extra watering is required. It will be noted that in formaldehyde beds extra watering is nowhere necessary. For the other three disinfectants it is more commonly necessary on very light sandy soils than on heary soils.

Air-slaked lime, powdered sulphur, and charcoal were applied dry, and in the tests reported by the writers were raked into the upper 3 inches of soil. Copper sulphate was applied in the form of dry powder in the tests reported by Spaulding. ${ }^{1}$ Sulphuric acid, formaldehyde, zinc chlorid, and in the tests reported by the writers copper sulphate were applied in solution. The strength of all treatments is expressed in the number of ounces of substance per square foot of bed. For sulphuric acid and formaldehyde the fluid ounce (29.574 c. c.) is the unit of measure, while for all other substances the avoirdupois ounce $(28.35 \mathrm{gm}$.) was used. Three-fourths of an ounce per square foot is practically equivalent to 1 ton per acre. The amount of water used in dissolving the disinfectants varies from 1 to $2 \frac{1}{2}$ pints per square foot. For a soil already wet 1 pint is sufficient; for a dry fine-textured soil $2 \frac{1}{2}$ pints may be needed to secure a proper distribution of the disinfectant. Ordinarily, $1 \frac{1}{2}$ or $1 \frac{3}{4}$ pints per square foot are satisfactory.

I Spaulding, Perley. The treatment of damping-off in coniferous seedlings. U. S. Dept. Agr., Bur。 Plant Indus. Circ. 4, 8 p. 1908. 


\section{COST OF DISINFECTANT TREATMENTS。}

Beoause of the diflerenoes between the nurseries where tests have been made, both in the details of the treatment used and in the scale of the operations and the equipment of the nursery in such matters as water supply, it is impossible to make any statement as to the exact costs of treatment.

At two of the nurseries (Fort Bayard, N. Mex., and Haugan, Mont.) mentioned in the foregoing pages, at which the treatments have been in use long enough to permit a definite statement, all that is needed is an application of acid solution to the beds just after sowing. The treated beds thereafter require no more attention than do those untreated. At six other nurseries, where the acid has been in use for a less time, the same appears to be true, while for a seventh nursery, where copper sulphate gives the best results, the same simple method of application appears satisfactory. For these nine nurseries, then, the treatment which has so far appeared most effective involves no expense except that of the single disinfectant application. Different amounts of disinfectant are required for different soils, and because of the rather high cost of transporting sulphuric acid the price of that disinfectant varies greatly in different localities, so that exact costs of the treatment can not be given. It is very evident, however, that both the sulphuric-acid and the copper-sulphate treatments applied in this way are decidedly cheaper than either the formaldehyde or heat disinfection methods as used in out-of-door seed beds of tobacco and other truck crops. At many railroad centers sulphuric acid can be obtained in carboy lots for $2 \frac{1}{2}$ cents per pound ${ }^{1}$ or even less, while copper sulphate should not ordinarily exceed 8 cents per pound. ${ }^{1}$ With copper sulphate onefourth avoirdupois ounce and sulphuric acid one-fourth fluid ounce per square foot will be sufficient or more than sufficient at most nurseries. Judging from the experience of truck-crop experimenters and from the results of the writers and others with formaldehyde at several nurseries, one-fourth to one-half fluid ounce per square foot of the more expensive formaldehyde will be needed on most soils to secure sufficient disinfection. If it develops that it is necessary to use the tight cover prescribed by most writers to prevent premature evaporation and to treat additional soil for use in covering the seed after sowing, these items will further increase the expense of formaldehyde treatment. The expense of steam disinfection of out-ofdoor seed beds of tobacco is given by Johnson ${ }^{2}$ as $\$ 7.50$ to $\$ 10$ per thousand square feet of bed. This is a much higher cost than is to be anticipated with acid or copper-sulphate treatment.

1 These prices prevailed pricr to the outbreak of the European war. It is assumed that the present higher prices are temporary.

2 Johnson, James. The control of diseases and insects of tobacco. Wis. Agr. Exp. Sta. Bul. 237, p. 10, 1914. 
Sugar, at first glance an excessively expensive amendment for use on soil, is not so much more expensive than formaldehyde in the quantities which appear of value in preventing damping-off at three of the, nurseries. If some unrefined sugar-bearing substance could be substituted for the table product used in the experiments, it is entirely possible that for certain soils sugar would become an economically satisfactory treatment for coniferous seed beds. Zinc chlorid also, while probably somewhat more expensive than formaldehyde, is not so costly as to be economically impossible on soils where it may prove to be the most effective disinfectant. Both of these substances are, however, decidedly more expensive than sulphuric acid or copper sulphate.

The most troublesome thing about the treatment with acid is that at some nurseries it is necessary to give treated beds frequent waterings during the germinating period for the protection of the roots of the seedlings against chemical injury. This has been found to be the case in acid plats at three nurseries, and with copper and zinc salts at one nursery, respectively, where these disinfectants have given evidence of greatest commercial value. At one of these nurseries (Halsey, Nebr.) figures are available which indicate the cost of the treatment with acid and subsequent watering. The additional labor cost of the seed sowing, due to the use with it of the acid application, was furnished by the forest officers. The figures follow.

Additional cost of seed beds at Halsey, Nebr., due to acid treatment, per 1,000 square feet (space occupied by paths excluded).

Cost of acid (allowing for freight, drayage, and waste)................ \$1.00

Additional labor in seed sowing, due to application of acid.............. .80

Labor cost of extra waterings required by acid beds during germinating period. $\quad 2.70$

Depreciation of containers for applying acid solution, and increasēd supervisory

cost (estimated), not to exceed............................... 50

Total charge against treatment. ......................... 5.00

The above figures were obtained in 1912. Subsequent changes in nursery practice have probably changed the costs, but no later figures are available.

This cost of $\$ 5$ per 1,000 square feet, or one-half cont per square foot of seed bed, would seem very high if put on an acreage basis. For extensive farming operations it would, of course, be excessivo. But because of the very high cost of coniferous seed and the very small area on which the seed-bed operations of even a large nursery are usually concentrated, this cost is easily offset by even a slight increase in the stand of seedlings sacured. The actual cost of production of seedlings is seldom less than 50 cents per thousand by the end of the first growing season. The prices commonly quoted by commercial nurseries for seedlings of most species which have remained in the 
sced bed for a second year run from four to ten times this figure. If the minimum stand commonly desired, i. e., 100 seedlings per square foot, is obtained on untreated beds, an increase in stand of only 20 per cent will mean an increased production of 20,000 seedlings, of a minimum value of $\$ 10$ for the 1,000 square feet taken as a unit. Even in this minimum case, therefore, the treatment may be considered to have paid for itself twice over. The ordinary net results should be still more favorable, for the following reasons:

(1) At nurseries where acid or copper sulphate can be used without especially frequent watering the cost of the treatment will be less than at Halsey. At only one other nursery has it been found necessary to water the treated beds as much as at Halsey.

(2) The average increase in stand resulting from the treatment is much greater than the 20 per cent used in the preceding calculations. Figures based on exact counts for two or more seasons are available from five localities (Halsey, the Kansas sand hills, Garden City, Fort Bayard, and Monument). The average increase in stand resulting from the best treatments at all of these nurseries is exactly 100 per cent.

(3) An additional advantage, of greater value than the average increase in stand, is the stabilization of ontput through the prevention of damping-off epidemics.

(4) A further advantage is the development of more uniform stands in the beds by the prevention of damping-off patches.

(5) In addition to the adyantages from increased stands and decreased damping-off, disinfectant treatment often has incidental results in the way of weed control or of increased growth of the conifers which may by themselves more than pay all costs connected with the treatment. These secondary advantages are discussed in the following paragraphs.

\section{SECONDARY ADVANTAGES FROM DISINFECTANT TREATMENTS.}

\section{STIMULATION OF GERMINATION CAUSED BY DISINFECTANTS.}

It is common and, in fact, almost invariable with all of the disinfectant treatments which have been successfully used to find a higher germination percentage in the treated plats than in the controls. In some cases this increase in germination (or, more accurately speaking, in the number of seedlings which appear above the soil surface) is very large. Whole groups of treated plats have in some cases given an apparent germination percentage three times that prevailing in the untreated plats in the same group. While such large increases are not common, it is a very frequent thing for the advantage in increased germination to be greater than that resulting from the control of damping-off after germination. (Compare the first and second columns under the head of "Relative results" in Tables I and II.) Such increases are mainly due to the control of parasites by the treatments; in the untreated plats Pythium and Rhizoctonia kill many secdlings or sprouting seeds before they break through the soil cover. However, in some cases at least, disinfectants, by direct action or by their effect on the soil, appear to cause seed to germinate which would otherwise have remained dormant. The advantage from this apparent stimulation of dormant seed can not be quanti- 
tatively separated from the advantage due to the control of parasites. The sum of the results of the treatments in stimulating germination, protecting the germinating seed from parasites, and in preventing damping-off are all cumulatively expressed by the increase in final stand in the treated over the untreated plats at the end of the season.

\section{INCREASED SIZE OF SEEDLINGS CAUSED BY DISINFECTANTS.}

At three of the nurseries where experiments were conducted for several seasons it was found that there was a distinct increase in the size of pine seedlings as a result of treatment with sulphuric acid. Immediately after the seedlings come up, the only effect, when there is a noticeable effect, is a decreased growth rate in the acid plats. This effect later disappears, and during the latter part of the season the seedlings normally grow faster in the acid plats than in the controls or in plats treated with most other disinfectants. At the nursery at Halsey during 1912 and 1913, seedlings were measured in five experimental series, three of jack pine, one of western yellow pine, and one of Norway pine. The average of all five shows that the acid caused an increase in height of 37 per cent.

At the nurseries in the Kansas sand hills and at Garden City acid had a much more surprising effect. The results with western yellow pine indicated a moderate increase in the first season's growth, in agreement with the Halsey results, this increase being still distinctly noticeable, at least at the sand-hill nursery, at the end of the second year's growth. But with jack pine at these nurseries unexpectedly large increases were secured. At both nurseries jack pine ordinarily makes a slow growth during the first scason. In plats sown in November, 1912, and treated with sulphuric acid carly the following spring, the average height of jack pine after a year's growth was found to be more than three times that of the seedlings in the untreated plats. The effect of acid treatment on the seedlings at the Garden City nursery is shown in Plate II, figure 1. At the Kansas sand-hill nursery, root systems as well as tops were examined. The increase. in root development appeared entirely commensurate with the increased size of the tops. The air-dry weight of the tops at the sand-hill nursery was $7 \frac{1}{2}$ times as great in these acid plats as in the untreated plats.

It is not to be expected that the acid will result in increased growth of any species in all soils, as the effect on growth is apparently due not to direct stimulation of the conifers, but rather to the effect of the acid on the soil. It is interesting to note that the only great increases in growth have been found at the nurseries where the soil water contained the largest quantities of acid carbonates.

The economic value of a moderate increase in growth, such as is secured at Halsey, depends largely on the system of handling stock. If the seedlings are to be held in the seed bed for two years an increase 
in the first season's growth is not very important. If, however, it is desired to transplant the stock at the end of the first season the increase in size due to acid, at least in the jack pine, which is ordinarily most helped, may mean the difference between suceess and failure. In a case of great increase in size, such as was secured by the acid treatment of jack pine at the two,nurseries in Kansas, the economic results are more positive. It was entirely impossible to raise 1-year-old stock large enough to transplant without the use of acid. With the acid treatment 1 -year-old seedlings were produced which appeared to be in every way the equal of untreated 2-year-old stock for transplanting purposes. The time and expense involved in holding the stock for a second year in the seed beds were avoided. At the Garden City nursery the advantage went even farther than that. The seedlings in the untreated beds were so small that they could not withstand winterkilling and were practically all killed before the second growing season. The seedlings in the acid plats immediately adjacent came through the winter practically without loss. While, as already stated, the acid proved ineffective at this nursery so far as the control of damping-off is concerned, on account of the carbonates present in the soil, its effect on growth and the resultant freedom from winter loss alone positively indicated its use on jack-pine beds in combination with the toxic salts found most valuable for damping-off control.

\section{WEED CONTROL BY DISINFECTANTS.}

At the nurseries where weeds are troublesome in the seed beds the effect of the disinfectants on the weeds is probably the most important of the secondary results of the treatment. The plants commonly occurring as weeds seem on the whole much more sensitive to acids and to copper and zinc salts than do the conifers. The result is that treatments so worked out as to be entirely harmless to the coniferous seedlings in the beds are found at a number of nurseries to keep the beds almost entirely free from weeds during the first three or four weeks after the germination of the conifers. This is just the time when most weeds can be expected to appear in the untreated beds and when the delicacy of the young conifers makes it difficult to do even hand weeding without breaking or pulling up many of the seedlings. The economic value of this weed-control feature varies with different nurseries. At some places the efficiency with which weeds are controlled is less than at others. At some places weeds are not numerous enough to make weed control a consideration of any very great importance. The only place at which an attempt has been made to reduce to a dollars-and-cents basis the value of the weedcontrolling effect of a damping-off control treatment is at Halsey, Nebr. Approximate figures obtained from forest officers indicate that the entire cost of the hand weeding required during the seasons consid- 
ered was approximately $\$ 7.60$ per 1,000 square feet; that for the season of 1912 the cost in the acid beds was $\$ 5.40$ less than in the untreated beds; and in 1913, $\$ 5.20$ less. This saving in cost of weeding exceeds the entire cost of the acid treatment as estimated during the first of these years. While the net value of weed control will not be as great as this in all seasons or at all nurseries, it appears that at several of the nurseries where tests have been carried on the benefit from weed control (Pl. II, fig. 2) or from increased growth of the seedlings, or from both of these effects combined, will be sufficient to more than justify the treatment. In such cases the control of damping-off secured by the treatments will be clear gain. It is especially interesting to note that in the seed beds of the Feather River Forest Experiment Station (California) a light sulphuric-acid treatment is in regular use simply on account of its value as a weed killer, entirely irrespective of any effect on damping-off.

\section{CONCLUSIONS AS TO SOIL DISINFECTANTS.}

The results listed in Table III indicate the complexity of the problem of soil treatment to control damping-off parasites. It is at once evident that a single season's experiments conducted on a single soil do not furnish a basis on which it is safe to make recommendations for general use. It furthermore appears that even after as extensive experiments as are here reported, it is not possible to prescribe any one treatment which will be safe and effective at all nurseries. Heat, the disinfecting agent most commonly employed by workers with truck soils, has proved inferior to other methods at all of the nurseries at which it has been tried. Sulphur, which is reported to have given excellent results against certain root diseases of other plants, has on the whole given disappointing results in pine seed beds. Formaldehyde, sulphuric acid, copper sulphate, and zinc chlorid, the four most generally satisfactory substances, have each failed at one or more nurseries. Especially at nurseries where no adequate watering system has been installed the frequent watering which beds treated with acid or with copper and zinc salts sometimes require means considerable trouble and expense.

However, after all these difficulties and drawbacks have been considered, analysis of the results indicates that it will be practicable to control damping-off by some soil treatment at any nursery where it is troublesome. The first part of Table III, containing results at the seven nurseries where repeated tests have been made, is, of course, the most important. At all of these nurseries soil treatment has proved successful. It is significant that at all but one of these seven sulphuric acid has proved successful. The acid failed at the seventh nursery only because of the high carbonate content of the soil, a condition rarely found at coniferous nurseries. At this seventh nursery 
the cheap and simple copper-sulphate treatment proved entirely satisfactory, with the alternative of zine chlorid in case the copper salt should ultimately prove in any way unsatisfactory. At four of the seven, all that appears necessary to be done is to apply the disinfectant, and thereafter let the beds take care of themselves. Although specially frequent watering is required during the germinating season by treated beds at the other three nurseries, the cost of this, as has been shown for Halsey, is not excessive, and the amount of extra watering required to protect the germinating seedlings at the remaining two nurseries is less than at Halsey.

At the localities considered in the last part of the table, where the tests have been mainly or entirely limited to a single scason, some facts of interest have been developed, though at none of them have the best control methods been definitely determined. At Dundee and Cass Lake a sufficient number of independent series of tests were made to show without doubt that some one of the treatments which resulted well will be found satisfactory for regular use. At most of the other nurseries in this second division the tests have been preliminary in character and are only indicative. At 13 of the 14 localities listed in the second part of the table, the results of the tests indicated the value of one or more of the treatments tested. At 9 of these 13 the indications were that the disease could be controlled by a treatment which would not make necessary any special watering of the beds. At the one nursery where no results were obtained (Pocatello) sulphuric acid was the only substance tested under proper watering conditions, and its failure is easily explained by the presence of soil carbonates.

Considering separately the soil treatments employed, it appears that there are four reasonably promising disinfectants for use on coniferous seed beds. The writers have experimented with approximately 50 different substances, alone or in combination, in the treatment of seed beds, and these tests, in conjunction with the results of the writers and of others which are summarized in Table III, indicate that the most generally satisfactory substances for such use are sulphuric acid, copper sulphate, zine chlorid, and formaldehyde, of which the acid is the most promising.

The use of sulphuric acid has been reported at 20 different localities. At 17 of these it has given indications of value. Its failure at Pocatello and Garden City is merely an indication that it will not succeed in the presence of large quantities of soil carbonates. At Glenview, Ill., the tests were very preliminary and therefore not sufficient to show that it was valueless. It has become established as a regular part of nursery practice at all nurseries where it has been repeatedly tested, with the exception noted of the one where the soil contained carbonates. At several nurseries in the 
Middle West, where the acid in single-season tests did not give as good results as other substances, there is reason to believe that the results of the acid treatment will be much better in normal scasons. The acid has to recommend it, in addition to its effectiveness against damping-off, the elements of cheapness, efficiency in killing weeds, and in many places of causing an increased growth of the conifers.

Copper sulphate, tested at 11 different places, gave no indications of value at three of them and very doubtful indications at the fourth. At the others it gave more or less indication of value, reaching the stage of regular nursery use at one nursery and at two others giving better results than the acid in single-season tests. Copper-sulphate treatment costs about the same as treatment with acid and is nearly or quite as effective in killing weeds, but has not been observed to result in any marked increase in growth of the conifers.

Data as to the value of zinc chlorid were secured from ten nurseries. At one of these it failed. At three others the tests were very preliminary, and while value was indicated the extent of value was not determined. At four it indicated value, but to a less extent than other treatments used. At the remaining two it indicated sufficient value to rank as a successful treatment. At both of the nurseries where it has been given repeated tests it has proved as good as any other treatment. At both of these, however, it has not been shown to be decidedly better than cheaper treatments (copper sulphate at Garden City and sulphuric acid at Fort Bayard), and therefore is not likely to replace them in regular use. Like copper sulphate, it kills weeds in addition to decreasing damping-off and has not been observed to cause increased growth of the conifers. The relatively high cost of this disinfectant, approximately one-half cent per square foot on heavy soils for material alone, is a point against it. Both copper sulphate and zinc chlorid cause injury to pines on some soils where acid seems entirely harmless. This means that their use will at most places necessitate more watering during the germinating period than is necessary when acid is used.

Data as to the value of formaldehyde in controlling damping-off have been secured from 12 places. At two of these it has failed. At another it has indicated value; extent undetermined. At five others it has indicated less value than sulphuric acid, while at the four remaining places it has been reported as successful. ${ }^{1}$ It. also kills weeds, has little effect on the growth of pines, and has the advantage of never making necessary any extra watering in treated plats. The points against it, in addition to its inferior efficiency in controlling damping-off at many nurseries, are its high cost and its tendency to kill seed if applied at or near the time of sowing. It is

1 At Dundee, formaldehyde alone was considered a failure, as the only successful formaldehyde plats were those also treated with zinc chlorid. 
necessary to treat beds some time before sowing, this period varying from two days to two weeks in different soils. The generally prescribed practice of covering the beds to prevent reinfection or premature evaporation of the formaldehyde during this period is troublesome and expensive. Further tests may prove it unnecessary.

In considering disinfectants, the ultimate as well as the immediate results should be taken into account. No data are at hand to show the effects of repeated treatments of soil with toxic salts or formaldehyde. The effects of single treatments seem to be purely temporary. Treatments of one-eighth and three-sixteenths ounce of copper sulphate per square foot (equivalent to 341 and 511 pounds per acre, respectively), which are expected to be quite sufficient for use against damping-off at most nurseries, involve additions of only one-sixth and one-fourth, respectively, of the amount which has been used in single treatments at Garden City without any noticeable permanent effect. Sulphuric acid might ultimately bring about an acid condition of the soil if used repeatedly, but this could be easily remedied at any time by the addition of lime. The only possible bad effect of continued use of the acid would therefore be an accumulation of sulphates. The sulphur added in a treatment of three-sixteenths fluid ounce of acid per square foot would be, roughly, 300 pounds per acre. If repeated every year, this would, of course, mean a considerable change in sulphur content. However, it would be a very rare thing for a treatment to be applied two consecutive years on the same soil, and where rotation is practiced five or six years commonly elapse between the growing of two crops of seedlings of susceptible species on the same soil. This minimizes the likelihood of any bad cumulative effect by the treatments.

The comparison of the four disinfectants considered in the foregoing paragraphs does not make possible a final statement as to their relative value. At most of the localities listed in Table III there have not been enough tests to give conclusive results. It is believed from the somewhat incomplete evidence secured that at most nurseries soil treatment with sulphuric acid will be found a satisfactory and probably the most satisfactory means of decreasing dampingoff and that where it is not satisfactory success can be secured with some one of the other disinfectants-copper sulphate, zine chlorid, or formaldehyde.

It is, of course, recognized that the treatments so far devised are not as simple and effective as are desired. Further tests of these disinfectants and of numerous others are under way. The problem of damping-off control is also being attacked from other directions than that of simple soil disinfection. It is hoped that a single disinfection method may be found which can be used on any soil and which will not require any unusual precautions against chemical injury; or, failing this, that some less direct procedure against the parasites 
will be found satisfactory. 'The securing' of final results along these lines will of necessity require sereral year's' experimenting, because of the differences between different soils and the number of species of parasites and of conifers which have to be considered. Meantime, the foregoing results are published to enable nurserymen to make use of the experience already gained. Under the following heading are outlined a number of treatments, at least one of which should be found successful and profitable at any coniferous nursery where damping-off is prevalent.

\section{SOIL TREATMENTS RECOMMENDED.}

No treatments can be guaranteed as either safe or effective on all soils. However, it is nearly certain that for any nursery at least one of the following will be found successful. It is therefore recommended that any nurseryman who has serious losses from dampingoff test some of these treatments on a small scale until he finds which one is best suited to his conditions. At least two successful tests should be made before a treatment is judged safe for large-scale use.

\section{Treatments for heavy soils.}

1. Sulphuric acid, three-sixteenths fluid ounce per square foot of bed, dissolved in from 1 to 2 pints of water per square foot of bed and applied immediately after the seed is sown and covered.

2. Same as treatment 1 , but use one-fourth ounce acid per square foot.

3. Copper sulphate, one-eighth avoirdupois ounce per square foot, dissolved in water and applied immediately after the seed is sown and covered.

4. Same as treatment 3, but use three-sixteenths ounce per square foot.

5. Zinc chlorid, one-half ounce per square foot, dissolved in water and applied immediately after the seed is sown and covered.

6. Formaldehyde, one-half fluid ounce per square foot, dissolved in water and applied 10 days before the seed is sown. Keep the bed covered with paper, tarpaulin, or tight shade frames during these 10 days. Do not spade up formaldehyde beds after treatment. If necessary to cover the seed with soil from outside of the plat, which has not been treated, use subsoil just dug up from at least 1 foot below the surface.

7. Same as treatment 6 , but apply the treatment only three days before sowing and do not cover with paper.

8. Air-slaked lime, one-half avoirdupois ounce per square foot, applied dry and raked into upper 3 inches of soil just before sowing. (If hydrated lime is used, threeeighths ounce per square foot will be sufficient.) Immediately after seed is sown and covered apply three-tenths ounce of sulphuric acid per square foot, dissolved in water.

9. Same as treatment 3 , but use one-fourth ounce per square foot.

In dissolving disinfectants, use sufficient water to make from 1 to 2 pints of solution per square foot. Two pints should be used if the soil is dry; 1 pint is sufficien' when the soil is wet.

\section{Treatments for sandy soils.}

1. Sulphuric acid, one-eighth fluid ounce per square foot, dissolved in water and applied immediately after the seed is sown and covered.

2. Same as treatment 1, but three-sixteenths ounce per square foot. 
3. Copper sulphate, one-tenth avoirdupois ounce per square foot, dissolved in water and applied immediately after the seed is sown and covered.

4. Same as treatment 3 , but one-sixth ounce per square foot.

5. Zinc chlorid, five-sixteenths avoirdupois ounce per square foot, dissolved in water and applied immediately after the seed is sown and covered.

6. Formaldehyde, five-sixteenths fluid ounce per square foot, dissolved in water and applied 10 days before seed is sown. Keep the bed covered with paper or tarpaulin during these 10 days. Do not spade up formaldehyde beds after treatment. If necessary to cover the seed with soil from outside of the plat, use subsoil just dug up from at least 1 foot below the surface.

7. Same as treatment 6, but apply only three days before seed sowing and do not cover beds with paper.

8. Air-slaked lime, three-eighths avoirdupois ounce per square foot, applied dry and raked into the upper 3 inches of soil just before sowing. (If hydrated lime is used, three-tenths ounce per square foot will be sufficient.) Immediately after the seed is sown and covered, apply one-fifth ounce of sulphuric acid per square foot, dissolved in water.

In dissolving disinfectants for sandy soils, use sufficient water to make from 1 to $1 \frac{1}{2}$ pints of solution per square foot. One and onehalf pints should be used if the soil is dry; 1 pint is sufficient if the soil is already wet.

\section{GENERAL DIRECTIONS FOR TREATMENTS.}

Commercial or technical grades of all the disinfectants are satisfactory. The sulphuric acid purchased should be concentrated, having a specific gravity of at least 1.82, while the formaldehyde solution, or "formalin" as it is sometimes called, should be the strongest obtainable, so-called 40 per cent solution, containing 37 per cent by weight. All disinfectants should be kept from the air as much as possible, as they change in strength if exposed. Copper sulphate requires the least care in this respect. Acid should be dissolved by pouring it into the water-never by the reverse process. Copper sulphate is quickest dissolved by putting it in a burlap sack and hanging it in the water just below the surface. Both of these solutions are corrosive to metal and should be handled only in wooden or earthenware containers and applied with sprinklers which have been coated inside with hot paraffin. ${ }^{1}$ Acid is also hard on the hands and clothes. Men who use it on a large scale are very careful to keep thair shoes heavily greased. Canvas gloves treated with hot paraffin or with a mixture of paraffin and a lighter grease, such as vaseline or lard, should be a valuable protection for the hands. The charring of wooden containers used in making up dilute acid solutions probably can be largely prevented by washing them out well with water containing washing soda before they

\footnotetext{
I To coat a sprinkler with paraffin, get the cake paraffin sold by grocerymen for use in sealing jelly and preserves. Shave off some of the paraffin into the sprinkler, and heat the sprinkler till all the paraffin is melted. Then turn the sprinkler around so that the liquid paraffin runs over the entire inside surface and finally pour what is left of the paraffin out through the spout. The whole can should be hot during the process, so that the paraflin will leave a thin coating; a thick coating cracks off too easily. The holes in the sprinkler head will have to be cleaned out with a pin or toothpick after the paraffin has hardened.
} 
are put away at the close of work. A coating of linseed oil, very thoroughly dried, should also prevent the charring of wood. Acid which gets on the hands does no harm if washed off at once with water. In applying treatments on a large seale the sprinklers used should have the holes in the rose or sprinkler head enlarged, to permit faster work.

In trying out the treatments in the foregoing lists, Nos. 1 and 2, the most promising, should be tested first. If both fail, the other

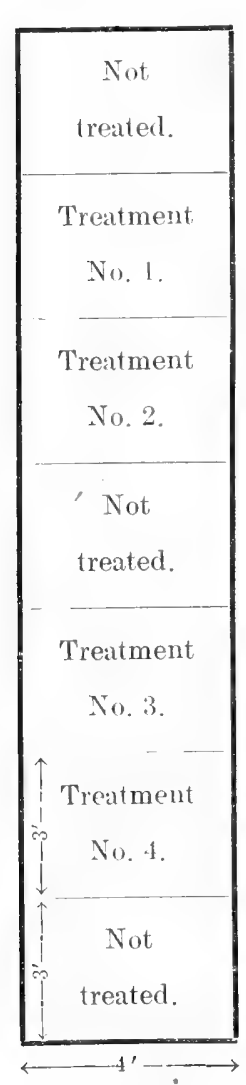
plats.
Frg. 1.-Suggested arrangement of test

treatments should be tried. If the acid solutions cause the soil to effervesce, some of the other treatments should be 'tried at once, as on such a soil the acid is likely to fail.

The treatments should be applied to small plats which are intermingled with untreated plats for comparison. For test plats, 3 by 4 feet has been found a convenient size. Good results can be obtained with even smaller areas than this, but all plats should be at least 2 feet wide. An arrangement of plats which the writers have found satisfactory is shown in figure 1. The seed for each plat, treated and untreated, should be measured out separately; so that all plats will get equal quantities of seed. Then the number of seedlings living on each plat at the end of the season will show which treatment is most valuable. In watering, shading, and in every other way treated plats should be handled just like the untreated beds, to make the test a fair one.

As soon as the seedlings begin to drop their seed coats, plats treated with acid, copper sulphate, or zine chlorid should be examined for chemical injury to the roots of the seedlings. ${ }^{1}$ If such chemical injury is found to occur, two courses will be open: (1) To test the same treatment again, watering the treated plats thoroughly every day from sowing till germination is complete; or, (2) to abandon the treatment which caused injury and try to get sufficient control of the disease by a weaker treatment or by another disinfectant. Treatments 6,7 , and 8 are inserted especially for use at places where acid causes injury and where frequent watering is not practicable; they are reasonably certain not to cause injury to seedlings under any circumstances.

1 The method of detecting chemical injury and illustrations of injured and uninjured seedlings have been given in a previous publication: Hartley, Carl. Injury by disinfectants to seeds and roots in sandy soils. U. S. Dept. Agr. Bul. 169, p. 9, pl. 1. 1915. This bulletin can be obtained by sending 5 cents in coin to the Superintendent of Documents, Government Printing Office, Washington, D. C. 


\section{SUMMARY.}

(1) By damping-off is meant the killing of very young seedlings by parasitic fungi. It is the most serious difficulty encountered in raising coniferous seedlings.

(2) To decrease losses from the disease excessive moisture and shade should be avoided. Caution must be used in following this recommendation or many seedlings may be killed by drought or by white-spot injury to the base of the stem. Damping-off can often be decreased by putting beds on very sandy soil. Seed should not be sown any thicker than necessary. It appears better to sow broadcast than in drills. Late fall sowing results in decreased losses at some núrseries and is worth trial. Proper attention to all of these measures will decrease the losses from damping-off, but at most nurseries they are not sufficient really to control the disease.

(3) The addition of lime, wood ashes, and in some cases nitrogenous fertilizers seems to increase damping-off. Soil alkalinity appears to favor the disease. No effect has been noted from green manures. The use of unrotted stable manure has had very bad results; properly rotted manures seem less objectionable. Tankage, charcoal, and cane sugar are the only nondisinfectant substances which to date have given any hope of disease control.

(4) Soil disinfection has so far proved the best method of combating damping-off. Of many methods tested, treatments with sulphuric acid, copper sulphate, zinc chlorid, and formaldehyde have proved the most satisfactory. The disinfectants behave quite differently at different nurseries. The results of treatments at many different localities are summarized in Table. III. The acid has on the whole given the best results. Heat disinfection has been only partly effective. Disinfection by acid or copper sulphate is cheaper than by the other methods commonly recommended.

(5) In addition to decreasing damping-off after the seedlings come up, the chemical disinfectants above mentioned, when properly used, cause an increase in the apparent germination and are very helpful in controlling weeds. This latter effect alone at some nurseries pays the entire expense of the treatment. Sulphuric acid has, furthermore, at some places resulted in marked increases in the late-season growth of pines. (See Pl. II.)

(6) In some soils formaldehyde kills dormant seed, and the other three most satisfactory disinfectants at some nurseries kill the root tips of germinating seedlings. By proper precaution, all such injury may be prevented.

(7) The results obtained to date show that it is entirely possible and practicable to control damping-off by soil disinfection. Unfortunately, the varying behavior of disinfectants at different places 
renders it impossible to recommend any single treatment which will be everywhere successful. Directions are given for simple tests, by which it is believed that any nurseryman can develop a treatroent that will succeed under his conditions.

(8) Further experiments are being conducted, with the hope of discovering either a more generally applicable disinfectant method than any of those so fur tested or else a means of controlling the disease without the use of disinfectants.

ADDITIONAL COPIES OF THIS PUBLICATION MAY BE PROCURED FROM

THE SUPERINTENDENT OF DOCUMENTS GOVERNMENT PRINTING OFFICE

WASHINGTON, D. C. AT

5 CENTS PER COPY $\nabla$ 

LIBRARY OF CONGRESS

00157936232 